\title{
Analysis Of International Ethical Standards In Accounting
}

Cheryl E. Mitchem, Virginia State University, USA

\begin{abstract}
This study examined the international standards regarding ethics education for professional accountants in the International Federation of Accountants' International Education Standard (IES 4) and International Education Practice Statement 1 and analyzed the curricula of a set of U.S. AACSB institutions to assess if they are meeting the ethics requirements. None of the schools selected for this study appears to have met the ethics requirements to an acceptable level; however, the private (religious-based) institutions examined came closer to the international model for ethical education for professional accountants. The study further suggests that the lost faith in the accounting profession and financial reporting system can only be regained by constructive efforts of U.S. regulators, educators and accounting professionals.
\end{abstract}

Keywords: International Accounting Standards, Ethics, Accounting.

\section{INTRODUCTION}

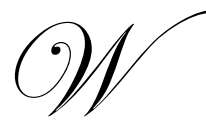

ith the Enron, WorldCom and Global Crossing (US), the H1H Insurance and One Tel (Australia) and the Parmalat (Italy) scandals early in the $21^{\text {st }}$ century, the investing public lost confidence in financial reporting worldwide. The implosion of Arthur Anderson led to public distrust of the accounting profession. These developments let to the Sarbanes-Oxley Act in 2002 (US) and the Corporate Law Economic Reform Program in 2004 (Australia) and the Higgs Review and Smith Report in 2003 in the U.K.

As regulation of the accounting profession by the Public Companies Accounting Oversight Board (PCAOB) and financial reporting by the Securities and Exchange Commission (SEC) increased in the U.S., efforts were made on many fronts to converge US GAAP with International Financial Reporting Standards (IFRS). The SEC is expected to announce this year that U.S. companies may use IFRS for financial reporting.

The accounting profession worldwide, but particularly in the U.S., must then focus on two objectives: 1) repairing the confidence lost by the scandals and 2) incorporating IFRS into financial reporting. While the profession struggles to educate practitioners on both ethics and IFRS, accounting educators in colleges and universities must try to teach their students about professional values, ethics and attitudes while at the same time incorporating a second set of standards (IFRS) into the already voluminous set of US GAAP. With the convergence of US GAAP and IFRS comes also the convergence of the AICPA Code of Professional Conduct with the International Federation of Accountants (IFAC) Code of Ethics for Professional Accountants (Allen and Bunting, 2008).

After convergence of the AICPA Code of Professional Conduct with the IFAC's Code of Ethics for Professional Accountants, accounting professionals and educators will need to review the pronouncements of the IFAC and the International Accounting Education Standards Board (IAESB), an independent standard-setting board within the IFAC, regarding ethics education and implement their recommendations.

The purpose of this study is two fold. First, to analyze the pronouncements of the IFAC and IAESB regarding the education of professional accountants in ethics as found in the IFAC's International Education Standard (IES) 4 "Professional Values, Ethics and Attitudes" (2005) and IAESB's International Education Practice 
Statement 1 (IEPS 1) "Approaches to Developing and Maintaining Professional Values, Ethics and Attitudes" (2007). Secondly, to analyze the curriculum of a set of AACSB peer institutions to determine if their curriculum is following the recommendations of IES 4 and IEPS 1. The paper will conclude with suggestions for accounting educators as to how to implement the recommendations of the IFAC and the IAESB for ethics education.

\section{LITERATURE REVIEW}

Prior to the release of IEPS 1, the IAESB released an information paper on "Approaches to the Development and Maintenance of Professional Values, Ethics and Attitudes in Accounting Education Programs. The purpose of this study was to assist in the development of IEPS 1 and to help accounting educators as they seek to implement ethics education programs for professional accountants.

When discussing ethics, the first question is-Can Ethics be Learned? There are a variety of attitudes regarding this question from uncertainty to total skepticism particularly in a capitalistic society. In the 1980s, Rest conducted research on moral development. Rest (1983) developed a four component framework for ethical behavior that consisted of: moral sensitivity; moral judgments; moral motivation and moral character. Rest found that deliberate educational attempts to influence moral development contributed to a person's moral perception and behavior. According to Kohlberg (1983), education is one of the crucial factors to develop and promote a student's ethical and moral development. Kohlberg (1969) developed the theory of cognitive moral reasoning and development that consisted of three levels: pre-conventional; conventional and post-conventional. Each level consisted to two stages. In the pre-conventional level, Stage 1 is a punishment and obedience orientation and Stage 2 is an instrument and relativity orientation. In the conventional level, Stage 3 is an interpersonal orientation and Stage 4 is a law and order orientation. In the post-conventional level, Stage 5 is a social contract orientation and Stage 6 involves the use of universal ethical principles. Education can advance one's moral awareness from one stage to the next. Both Rest and Kohlberg have suggested that ethics can be taught.

The challenge for accounting educators is to teach professional values, ethics, and attitudes, while "empirical evidence indicates that the ethical sensitivity of accounting and business students do not compare favorably to groups with comparative educational backgrounds" (IAESB, 2006, p.31). Evidence of this lack of ethical sensitivity is displayed in studies by Lane and Schaupp, 1989: Lane, 1996; Merritt, 1991; McPhail and Gray, 1996; Haswell and Jubb, 1995; Cree and Baring, 1991; Bernardi et al, 2004; and Lord and Melvin, 1997.

In the US, accounting educators have predominately attempted to integrate ethical education into the accounting curriculum, primarily in the auditing, income tax and intermediate accounting courses. Madison and Schmidt (2006) reported AACSB institutions devoted an average of 7.5\% of total class time or 25.6 hours to ethics instruction in their accounting programs. However, Blanthorne et al., 2007, in their survey of US accounting faculty found that over $45 \%$ of the faculty thought that ethics instruction in their department was insufficient and over $75 \%$ of the survey respondents thought that they could incorporate more ethics into their courses.

In 2005 the education committee of the National Association of State Boards of Accountancy (NASBA) issued an exposure draft to change the education requirements to sit for the CPA examination of the Uniform Accountancy Act (UAA) to include the additional of three credit hours in business ethics and three credit hours in accounting ethics. The reactions from the American Accounting Association (AAA 2005), the Association for the Advancement of Collegiate Schools of Business (AACSB 2005) and accounting educators were extremely negative according to Blanthorne et al., (2007). Accounting educators prefer to integrate ethics into individual course curriculum (Madison and Schmidt, 2006; Blanthorne et al., 2007).

The NASBA issued its revised ethics requirements in August, 2007, to state that an accounting course in ethics could be one of twelve topics taught in 24 semester hours of accounting or that a business ethics course could be one of the eleven topics taught in 24 semester hours of business. While the NASBA proposal stated that any accounting program "should include and emphasize ethical behavior and professional responsibility" (NASVA Rule 5.2), no specific accounting and/or business ethics course(s) were required. However, four state boards of 
accountancy (Texas, Maryland, New York and Nebraska) have added requirements for ethics education as a prerequisite for CPA licensure (Hurtt and Thomas, 2008).

Madison and Schmidt (2006) found in their survey of large accounting program department chairs that 70\% of the respondents believed "that ethics should be integrated into the business and accounting courses and not established as a separate required class developed to the subject of ethics in business and accounting" (p. 108). In their survey of accounting faculty, Blanthorne et al., (2007) found "that $92 \%$ of faculty favors inclusion of ethics in the curriculum" (p. 383) and that the average faculty member spent about 4.4 hours per course on ethics (p. 384). According to Blanthorne et al. (2007), if ethics education is to be required as encouraged by AACSB and NASBA, then more integration of ethics into the curriculum will be necessary.

While ethics education in the US has increased over the last decade, additional ethical education will be required as the AICPA Code of Professional Conduct and the IFAC Code of Ethics for Professional Accountants converge and IES 4 and IEPS 1 become effective.

\section{RESEARCH METHODOLOGY}

The purpose of this study is two-fold. First, to analyze the pronouncements of the IFAC and IAESB regarding the education of professional accountants as found in IES4 and IEPS1. Secondly, to analyze the curricula of a set of U.S. AACSB peer institution to determine if each school's curriculum is following IFAC recommendations.

The two studies mentioned in the last section of this paper, surveyed large accounting departments and accounting faculty, respectively. Curriculum design is a long process. Any curriculum change is more evolutionary than revolutionary. Larger schools are very slow to change their curriculum. Therefore, as mentioned in the introduction, the second purpose of this study is to analyze the accounting curricula of a sample of 25 small AACSB peer institutions. The websites of each school of business were examined to determine if they had revised their basic course and program requirements to include either the teaching of business ethics as a separate course and or the teaching of accounting ethics as a separate course. Additionally, the mission statements and schools goals and objectives were reviewed to determine if ethics was mentioned in either.

\section{ANALYSIS OF PROFESSIONAL VALUES, ETHICS AND ATTITUDES IN IFAC AND IAESB STANDARDS}

In IES 4, the professional values, ethics and attitudes that professional accountants should acquire during the education process are prescribed. "Professional values, ethics and attitudes need to be treated in their own right within the education framework....It is essential that they do not perceive the treatment of professional values, ethics and attitudes as peripheral to their own main education program" (para. 8). Ethical development can not be ignored in the education process and must "begin early in the education of a professional accountant" (para. 9).

In the section on Professional Values, Ethics and Attitudes (para.16), IES 4 states that at a minimum all programs should cover the follow topics: the nature of ethics; differences between rule-based and principles based approaches to ethics; compliance with the fundamental principles of integrity, objectivity, professional competence, due care and confidentiality; professional behavior and compliance with standards; concepts of independence, skepticism, accountability and public expectations; ethics and the profession; social responsibility; ethics and law; ethics in relation to business and good governance; ethics and the individual accountant; whistle blowing, conflicts of interest and ethical dilemmas and their resolution and the consequences of unethical behavior to the individual, profession and society.

Later in "Teaching Professional Values, Ethics and Attitudes" (paragraphs 17-22), IES 4 discusses participative approaches can enhance the presentation of professional values, ethics and attitudes. Examples may include the following: multi-dimensional case studies; role playing; selected readings and videos; analysis of real life ethical dilemmas; discussion of disciplinary pronouncements and speakers (para. 20).The standard concludes with the statement that "proper ethical behavior is as important as technical competence" (para. 23). 
IEPS 1 “Approaches to Developing and Maintaining Professional Values, Ethics and Attitudes" (2007) was written to provide guidance on implementing IES 4. IEPS 1 sets out two possible approaches to the development of professional values, ethics and attitudes and provides guidance on a number of methods for the delivery of ethics education.

There are five threats to ethical compliance outlined in the IFAC Code of Ethics: self-interest, self-review, advocacy, familiarity and intimidation (para. 10). The IFAC Code of Ethics sets out safeguards that can reduce the threats to an acceptable level or eliminate them: safeguards created by the profession and in the work environment (para. 11). The safeguards created by the profession include the educational experiences necessary for the professional accountant.

In the section devoted to Developing Ethical Competence (para.14-30), the ethics education continuum (EEC) is explained. The EEC identified four stages in an ethics education learning continuum. Stage 1-enhancing ethics knowledge; Stage 2-developing ethics sensitivity; Stage 3-improving ethical judgment; and Stage 4maintaining an ongoing commitment to ethical behavior.

In Stage 1-Enhancing ethics knowledge focuses on developing an understanding of: relevant standards and codes; expectations of ethical and professional conduct; fundamental theories and principles of ethics, virtues and individual moral development. In Stage 2-Develops ethical sensitivity to ethical threats; awareness of alternative courses of ethical solutions and knowledge about the effects of each alternative solution on the stakeholders. This stage applies ethical principles to accounting courses. In Stage 3-Improves ethical sensitivity as students learn to integrate and apply ethical knowledge and sensitivity to make decisions. Stage 4-maintains an ongoing commitment to ethical behavior through continuing professional education.

In the second section of IEPS 2, two possible approaches to implement the EEC are discussed; the topic approach (para.33) and the stage-by-stage approach (para. 37). The two approaches may be used separately or mixed.

\section{The Topic Approach}

\begin{tabular}{|l|l|}
\hline \multicolumn{1}{|c|}{ EEC Subject Area } & \multicolumn{1}{c|}{ IES 4 Topics } \\
\hline $\begin{array}{l}\text { A framework approach } \\
\text { Concepts and values }\end{array}$ & $\begin{array}{l}\text { The nature of ethics } \\
\text { Differences between rule-based and principles based approaches to ethics }\end{array}$ \\
\hline $\begin{array}{l}\text { The corporate, professional and } \\
\text { regulatory environment }\end{array}$ & $\begin{array}{l}\text { Ethical principles of integrity, objectivity, competence, due care and confidentiality } \\
\text { Compliance with technical standards } \\
\text { Concepts of independence, skepticism, accountability and public expectations } \\
\text { Ethics and law }\end{array}$ \\
\hline Decision making & Whistle blowing, conflicts of interest and the resolution of ethical dilemmas \\
\hline Ethical threats and safeguards & Consequences of unethical behavior to the individual, profession and society \\
\hline $\begin{array}{l}\text { Corporate governance } \\
\text { Social and environmental issues }\end{array}$ & $\begin{array}{l}\text { Social responsibility } \\
\text { Ethics in relation to good governance and business }\end{array}$ \\
\hline
\end{tabular}

"The Topic Approach integrates the first stages of the EEC subject by subject in relevant parts of the...program. Each subject can be learned progressively following the first three stages of the EEC learning continuum.

In paragraph 38, "this approach typically begins by introducing ethics early in the pre-qualification program (Stage 1), followed by ethical discussion in the existing accounting modules or courses (Stage 2), and culminating in a final module/course that ties together previous ethics material (Stage 3)". 
The Stage-by-Stage Approach

\begin{tabular}{|c|l|l|l|}
\hline Stage & \multicolumn{1}{|c|}{ Attribute } & \multicolumn{1}{|c|}{ Learning Outcome } & \multicolumn{1}{c|}{ Illustrative Method } \\
\hline 1 & $\begin{array}{l}\text { Enhancing ethical } \\
\text { knowledge }\end{array}$ & $\begin{array}{l}\text { Knowledge of relevant standards } \\
\text { and expectations of ethical and } \\
\text { professional conduct }\end{array}$ & $\begin{array}{l}\text { Separate, assess course or module early in the } \\
\text { education program. }\end{array}$ \\
\hline 2 & $\begin{array}{l}\text { Developing ethical } \\
\text { sensitivity }\end{array}$ & $\begin{array}{l}\text { Developing ethical sensitivity and } \\
\text { an appreciation of ethical threats } \\
\text { and safeguards. }\end{array}$ & $\begin{array}{l}\text { Integration of ethical issues in different courses, i.e. } \\
\text { financial and managerial accounting, tax accounting } \\
\text { and auditing }\end{array}$ \\
\hline 3 & $\begin{array}{l}\text { Improving ethical } \\
\text { judgment }\end{array}$ & $\begin{array}{l}\text { Improving ethical judgment by } \\
\text { sharpening ethical decision } \\
\text { making skills. }\end{array}$ & $\begin{array}{l}\text { Integrated final course or module and assessment } \\
\text { including case studies and/or a separate, assessed } \\
\text { final course or module in ethics. }\end{array}$ \\
\hline 4 & $\begin{array}{l}\text { Maintaining an } \\
\text { ongoing commitment } \\
\text { to ethical behavior }\end{array}$ & Commitment to ethical behavior & $\begin{array}{l}\text { Ongoing experience and continuing professional } \\
\text { education. }\end{array}$ \\
\hline
\end{tabular}

In paragraph 54 of IEPS 1, several suggested teaching methods are suggested: lectures; ethics discussions; collaborative learning; case studies; role-playing; guest speakers and e-learning. In the educational setting, the assessment of the development of ethical knowledge, ethical sensitivity and ethical judgment can be conducted by the following methods: tests based on case studies, student journals based on a case analysis system; objective testing of ethics; and group case assignments to assess students' competence in ethical analysis and decisionmaking.

Thus, it would appear that one way to implement IES 4 and IEPS 1 would be to: require a business ethics course early in the curriculum; integrate ethics in the different topical accounting courses; and conclude with a senior level accounting ethics course.

\section{ANALYSIS OF ETHICAL ENDEAVORS IN AN AASCB PEER GROUP}

The second part of this study was to analyze the curriculum of a set of AACSB peer institutions to determine if their curriculum is following the recommendations of IES 4 and IEPS 1. The AACSB peer institutions included 12 public institutions and 13 private institutions. As shown in Figure 1, ethics was mentioned as part of the university's mission statement in one institution. Ethics was mentioned in the school of business mission statement or goals and objectives in fifteen of the institutions surveyed. One accounting department mentioned ethics, but eight of the institutions analyzed did not mention ethics as either a part of their mission statement or as a goal or objective. This is surprising given that the AACSB does require coverage on ethics to be documented in coursework.

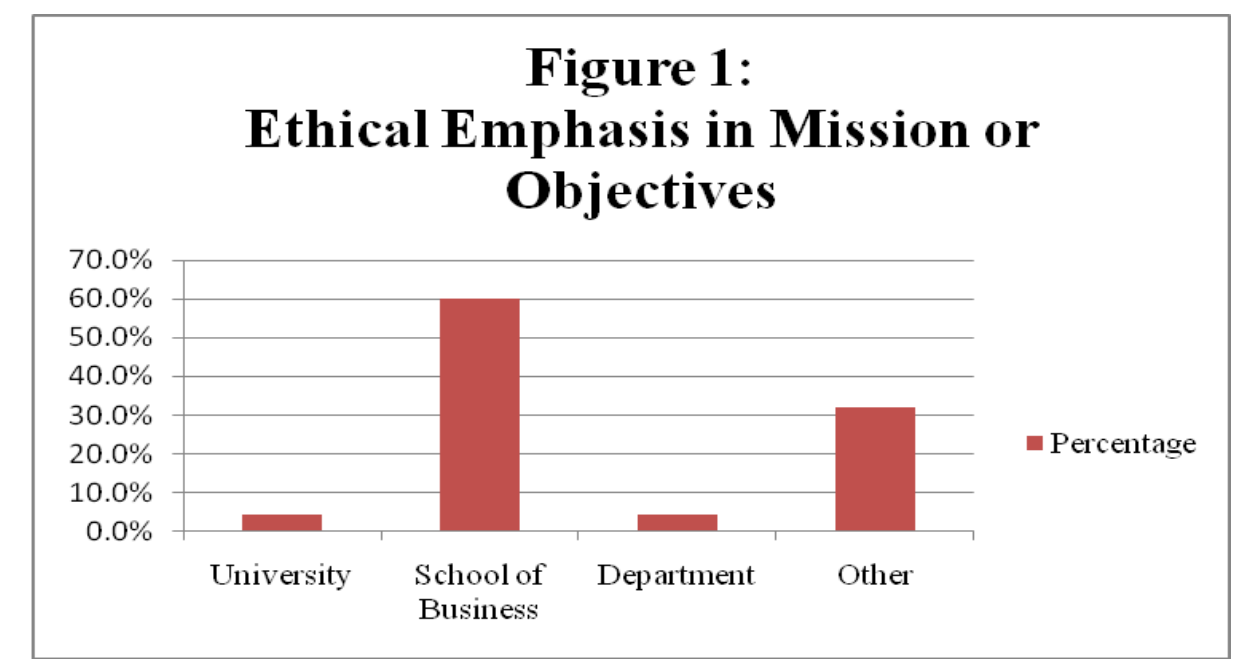


As shown in figure 2, the breakdown between public and private institutions showed similar results with a majority of the both public and private schools identifying ethical training an objective or goal of their program. However, four public and four private schools did not mention ethics in the description of their program. In the sample of private institutions, seven of the 13 schools mentioned ethics in the mission, goals/objectives section of their webpage. One university stated that ethics was in their mission statement and one accounting department had ethics in their mission statement. Two institutions did not mention ethics at all and two others used different terminology. One school wanted their students to be socially responsible and another school of business stated that accountability and ethics is a competency. What is surprising is that six different schools of business did not mention ethics or a similar concept in their mission statement or goals and objectives. The private institutions did appear to be slightly more responsive to the ideal of ethics education for their undergraduates.

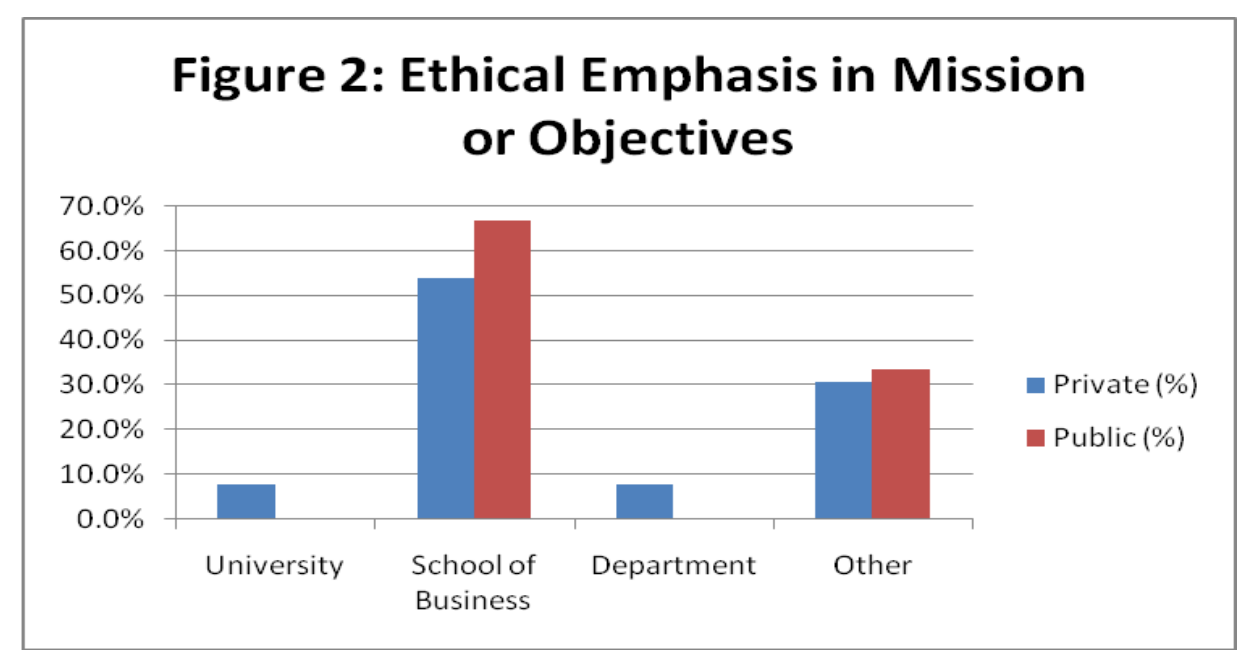

In the curriculum section of each school's website, nine of the public institutions did not require either an ethics or business ethics course as part of their curriculum. However, one school that did not required an ethics course offered three one credit courses in professional development and another school that did not require ethics had a three credit elective course in ethics or applied ethics and a one credit course titled "The Accounting Profession". Three public institutions did require ethics or business ethics as a required course.

Of the thirteen private institutions, four required a course in ethics or business ethics. One of the four schools also required three credit hours in business law and ethics for financial professionals. Another of the schools required three hours in legal and social responsibility, three hours in professional development and three hours in philosophy. While another private school also required four hours in philosophy and eight hours in religion. One of the four private schools required a five hours course in ethics and an additional five hours in theology and religious studies.

A total of nine public and nine private schools did not require either a business ethics or an ethics course. The private schools, however, often required similar humanities related course, i.e. religious studies or theology; philosophy; ethics, diversity and social responsibility; legal and social responsibility; and professional development. Of the nine public institutions that did not offer a required ethics or business ethics course, one school required a three credit course in professional development and a second school required a one credit course in the accounting profession. The number of humanities related course credit hours, both public and private, is reflected in figure 4 . 

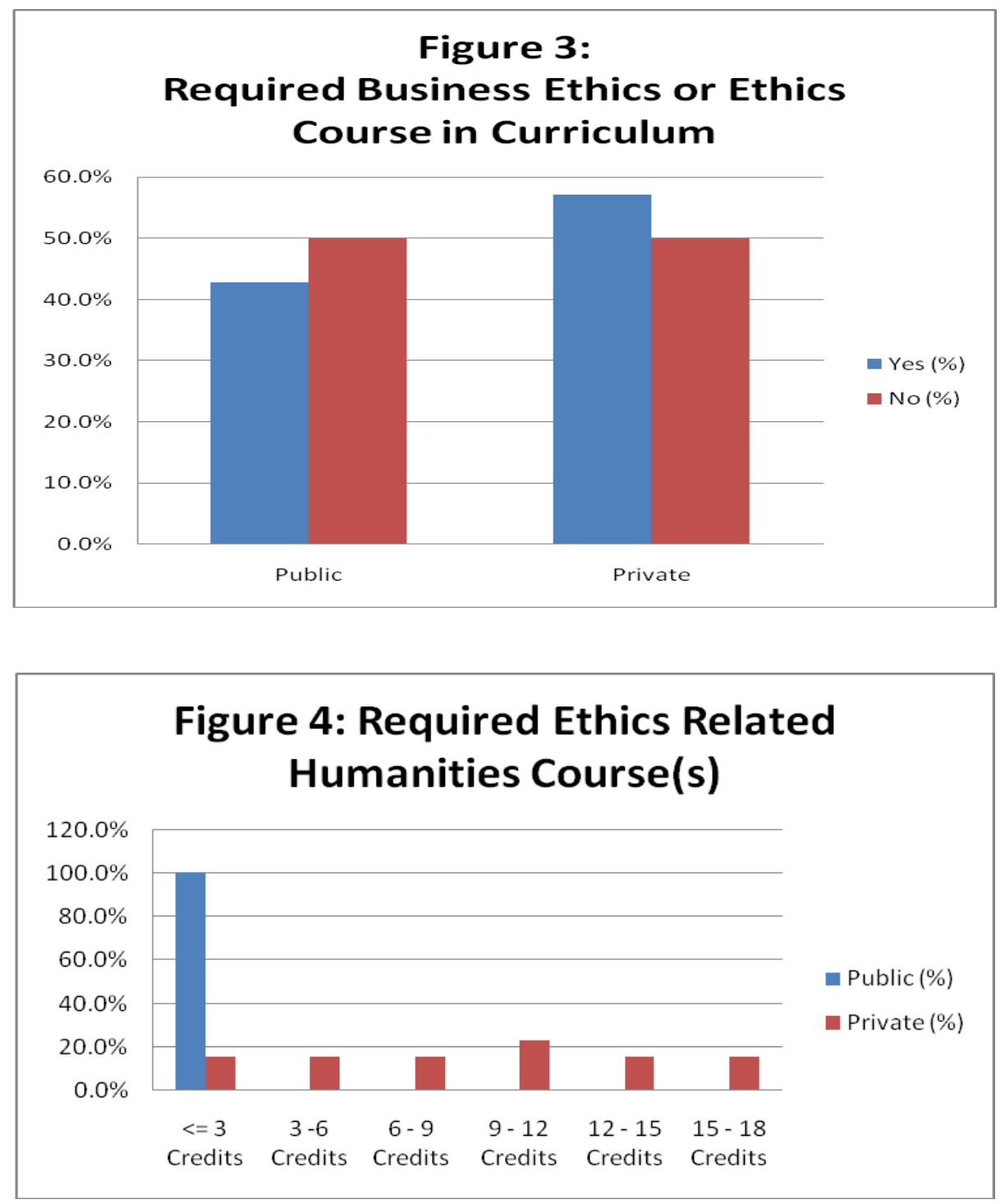

The last curriculum item to be examined was the course in accounting ethics. 24 of the 25 AACSB institutions did not require a course in accounting ethics. One private institution, however, did require that all accounting and finance majors take an upper level course in business law and ethics.

\section{CONCLUSIONS AND RECOMMENDATIONS}

The purpose of this study was two-fold. First, to analyze the pronouncements of the IFAC and IAESB regarding the education of professional accountants as found in IES 4 and IEPS1. Secondly, to analyze the curricula of a set of U.S. AACSB peer institutions to determine if each school's curriculum is following IFAC recommendations. One of the limitations of this study was the focus on only a small sample of AACSB institutions. Further extensions of this study could survey additional schools and accounting educators.

As the US GAAP and IFRS converge, the AICPA Code of Professional Conduct will converge with the IFAC code of Professional Accountants. The IFAC in IES 4 and IEPS 1 recommend that ethics be taught in three segments: first, a business ethics course early in the curriculum; second integration into the different topical 
accounting courses and finally with a senior level accounting ethics course. "Proper ethical behavior is as important as technical competence" (IES 4, para. 23).

In the U.S., the AAA, the AACSB and accounting educators responded negatively to a recommendation by the NASBA to require a three credit course in business ethics and a three credit course in accounting ethics to sit for the CPA examination in 2005. Under pressure, NASBA withdrew its recommendation.

In a review of AACSB peer institutions curricula, no schools had implemented all the requirements of IES 4 and IEPS 1 . The private institutions appear to have embraced the concept of ethics education more than the public institutions. While $92 \%$ of accounting faculty favor the inclusion of ethics in the curriculum (Blanthorne et al., 2007), more is needed.

Full integration of ethical education into the curriculum may not occur unless mandated by a regulatory agency. Accounting educators should prepare for both the convergence of IFRS with US GAAP and the inclusion of broad ethical coverage in the curriculum. Full ethics coverage must include a required business ethics course, integration of ethics into the topical accounting courses and a senior accounting ethics course.

\section{AUTHOR INFORMATION}

Cheryl E. Mitchem, Ph.D., CPA, CMA is the Acting Assistant Dean and an Associate Professor in the School of Business at Virginia State University in Petersburg, Virginia.

\section{REFERENCES}

1. Allen, C. and Bunting, R. "A Global Standard for Professional Ethics". Journal of Accountancy, May 2008, 46-52.

2. American Accounting Association. "AAA Task Force Position Statement on the NASBA Exposure Draft", 2005.

3. The Association to Advance Collegiate Schools of Business. "AACSB Comment Letter to NASBA", 2005.

4. Bernardi, R., Metzger, R., Scofield Bruno, R., Wade Hoogkamp, M, Reyes, L and Banaby, G. "Examining the Decision Making Process of Students Cheating Behavior: An Empirical Study". Journal of Business Ethics, 50, 2004, 397-414.

5. Blanthorne, C., Kovar, S. and Fisher, D. “Accounting Educators' Opinions about Ethics in the Curriculum: An Extensive View”. Issues in Accounting Education, 22 (3), August 2007, 355-390.

6. Cree, M. and Baring, G. "Desperately Seeking Ethics", Australian Accountant, July 1991, 25-26.

7. Haswell, S. and Jubb, P. "Unethical Tendencies". Charter, April 1995, 102-103.

8. Hurtt, R. and Thomas, C. "Implementing a Required Ethics Class for Students in Accounting: The Texas Experience". Issues in Accounting Education, 23(1), February 2008, 31-51.

9. International Federation of Accountants (IFAC)", International Education Practice Statement 1, Approaches to Developing and Maintaining Professional Values, Ethics and Attitudes", 2007.

10. __ "International Education Standard 4 Professional Values, Ethics and Attitudes", 2003.

11. _ "Approaches to the Development and Maintenance of Professional Values, Ethics and Attitudes in Accounting Education Programs-Information Paper", 2006.

12. Kohlberg, L. "Stage and Sequence: The Cognitive Development Approach to Socialization". Handbook of Socialization Theory and Research, ed. Goslin, D., Rand McNally, New York, 1969, 347-480.

13. Kohlberg, L. The Philosophy of Moral Development, Harper and Row, San Francisco, Ca., 1983.

14. Lane, J. "Ethics of Business Students: Some Marketing Perspectives". Business Ethics in Australia and New Zealand Essays and Cases, ed. Woldring K., Thomas Nelson, South Melbourne, Australia, 1996, 262 272.

15. Lane, M. and Schaupp, D. "Ethics in Education: A Comparative Study". Journal of Business Ethics, 8, 1989, 943-949.

16. Lord, A. and Melvin, K. "The Attitudes of Accounting Students, Faculty and Employers Toward Cheating”. Research in Accounting Ethics, 3, 1997, 1-20. 
17. Madison, R. and Schmidt, J. "Survey of Time Devoted to Ethics in Accountancy Programs in North American Colleges and Universities”. Issues in Accounting Education, 21(2), May 2006, 99-109.

18. McPhail, K. and Gray, R. Not Developing Ethical Maturity in Accounting Education: Hegemony, Dissonance and Homogeneity in Accounting Student's World Views, University of Dundee, The Centre for Social and Environmental Accounting Research, 1996.

19. Merritt, S. "Marketing Ethics and Education: Some Empirical Finds". Journal of Business Ethics, 10, 1991, 625-632.

20. National Association of State Boards of Accountancy (NASBA), Rules 5-1 and 5-2 Exposure DraftEducation Requirements, August 24, 2007.

21. Rest, J. "Morality" _Handbook of Child Psychology $4^{\text {th }}$ ed., ed. Mussen, P. John Wiley \& Sons, New York, 1983.

\section{NOTES}


NOTES 